\title{
METHODOLOGY FOR ASSESSING THE QUALITY OF EDUCATIONAL SERVICES IN HIGHER EDUCATION
}

\author{
METODOLOGIA PARA AVALIAÇÃO DA QUALIDADE DOS SERVIÇOS DE \\ EDUCAÇÃO SUPERIOR
}

\author{
METODOLOGÍA PARA EVALUAR LA CALIDAD DE LOS SERVICIOS EDUCATIVOS \\ EN LA EDUCACIÓN SUPERIOR
}

\author{
Marina VINOGRADOVA ${ }^{1}$ \\ Olga KULYAMINA ${ }^{2}$ \\ Lidia VASILEVA ${ }^{3}$ \\ Evgeniya BRONNIKOVA ${ }^{4}$ \\ Viktoriya VISHNYAKOVA ${ }^{5}$
}

\begin{abstract}
The article examines the criteria and indicators for assessing the quality of educational services. The coverage of the topic of this article passes through the prism of factors related to the assessment of educational services quality, which allowed the authors to identify current methodological problems, as well as to emphasize the importance of using an integrated approach in studying the issues of providing educational services. The authors identify criteria and indicators for assessing of educational services. The authors developed the composite coefficient of educational services quality. The practical implementation of the proposals prepared by the authors determines the prerequisites for the development of a methodology for assessing educational services quality, which will allow for an objective assessment and, as a result, take the necessary measures to improve the quality of educational services on the part of the educational organization.
\end{abstract}

KEYWORDS: Assessment. Educational services. Educational organization. Educational services quality.

RESUMO: $O$ artigo examina os critérios e indicadores para avaliar a qualidade dos serviços educacionais. A cobertura do tema deste artigo passa pelo prisma de fatores relacionados à avaliação da qualidade dos serviços educacionais, o que permitiu aos autores identificar problemas metodológicos atuais, bem como enfatizar a importância do uso de uma abordagem

${ }^{1}$ Russian State Social University, Moscow - Russia. Doctor of Economics, Vice-Rector for Research. ORCID: https://orcid.org/0000-0002-5051-9404.E-mail: m_vinogradova@gmail.com

${ }^{2}$ Russian State Social University, Moscow - Russia. Candidate of Economics, Head of Interdisciplinary Research Laboratory. ORCID: https://orcid.org/0000-0001-7715-5551.E-mail: kulyamina_o@gmail.com

${ }^{3}$ Russian State Social University, Moscow - Russia. Researcher, Scientific and Research Institute of Prospective Trends and Technologies. ORCID: https://orcid.org/0000-0002-5311-7099. E-mail: vasileva47@gmail.com

${ }^{4}$ Russian State Social University, Moscow - Russia. Candidate of Economics, Senior Researcher, Interdisciplinary Research Laboratory. ORCID: https://orcid.org/0000-0002-5409-9726. E-mail: 85614863@gmail.com

${ }^{5}$ Russian State Social University, Moscow - Russia. Candidate of Economics, Head of Department of Scientific and Technical Information. ORCID: https://orcid.org/0000-0001-5986-2498. E-mail: education.com.ru@gmail.com 
integrada no estudo das questões de fornecimento de serviços educacionais. Os autores identificam critérios e indicadores para avaliar os serviços educacionais. Os autores desenvolveram o coeficiente composto de qualidade dos serviços educacionais. A implementação prática das propostas elaboradas pelos autores determina os pré-requisitos para o desenvolvimento de uma metodologia de avaliação da qualidade dos serviços educacionais, que permitirá uma avaliação objetiva e, por conseguinte, tomar as medidas necessárias para a melhoria da qualidade dos serviços educacionais da organização educacional.

PALAVRAS-CHAVE: Avaliação. Serviços educacionais. Organização educacional. Qualidade dos serviços educacionais.

RESUMEN: El artículo examina los criterios e indicadores para evaluar la calidad de los servicios educativos. La cobertura del tema de este artículo pasa por el prisma de los factores relacionados con la evaluación de la calidad de los servicios educativos, lo que permitió a los autores identificar los problemas metodológicos actuales, así como enfatizar la importancia de utilizar un enfoque integrado en el estudio de las cuestiones de brindando servicios educativos. Los autores identifican criterios e indicadores para la evaluación de los servicios educativos. Los autores desarrollaron el coeficiente compuesto de calidad de los servicios educativos. La puesta en práctica de las propuestas elaboradas por los autores determina las condiciones previas para el desarrollo de una metodología de evaluación de la calidad de los servicios educativos, que permitirá realizar una evaluación objetiva y, en consecuencia, tomar las medidas necesarias para mejorar la calidad de los servicios educativos en parte de la organización educativa.

PALABRAS CLAVE: Evaluación. Servicios educativos. Organización educativa. Calidad de los servicios educativos.

\section{Introduction}

Nowadays, there is a fierce competition in the educational services market. Only the educational organization that is continuously engaged in quality improvement issues can win in it. Currently, there is no single methodology for assessing the educational services quality to recommend to all educational organizations. Therefore, the universities force to develop criteria and indicators of the educational services quality at the level of self-examination. The need to assess the educational services quality is due to the interest of society and the state in ensuring that the population mastered significant and necessary competencies to maintain the quality of work at a certain level. It should grow in proportion to the development of science and technology, providing the labor market with qualified personnel (GERRITSEN-VAN LEEUWENKAMP; JOOSTEN-TEN BRINKE; KESTER, 2017). This fact forms several mandatory characteristics that are significant for a particular consumer of educational services. 
The variety of methods and approaches for assessing the educational services quality has its own specifics and often does not allow making objective analysis timely and qualitatively. In this regard, the issue of assessing the provision of educational services requires a detailed study.

\section{Methods}

In order to analyze the effectiveness of evaluating the educational services quality in the course of the study there were used methods of comparative analysis, which revealed the main approaches to the assessment of educational services. The set of general scientific methods made it possible to determine the main criteria and indicators for assessing the quality of educational services.

The work also considered the approaches of Russian and foreign scientists to the definition of educational services quality (ASANOVA; SERGEEVA, 2019, GERRITSENVAN LEEUWENKAMP; JOOSTEN-TEN BRINKE; KESTER, BERZINA; ZICMANE; KUCKOVSKIS, 2017), the concept of quality in higher education (ESCOBAR-JIMENEZ; DELGADO, 2019), the approaches to education management (PANASYUK, 2017). The features of the methodology for the transition to e-education, transformation of higher education, the introduction of an electronic environment was analyzed (CARCAMO, 2021, VERETEKHINA; NOVIKOVA, 2019). The quality of higher education, influencing factors, assessment systems (BOLOTOV, 2018; ZHANG; LI; LI, 2019; ILICHENKO, 2017), including issues of assessing the quality of the teaching staff (GONZALEZ-GERALDO; MONROY; DEL RINCON IGEA, 2021) assessment of student's satisfaction with the quality of educational services were studied (VELICHKO et al., 2020).

As part of the analysis, special attention was paid to legislative regulations and standards of the Russian Federation (Federal Law of December 29, 2012 № 273-FZ, GOST R 506912013, form number 1-Monitoring, Reference information Federal State Educational Standards, Statistical reporting forms) (RUSSIA, 2012; 2013; 2019).

The main goal of the study is to develop a methodology for assessing the quality of educational services in higher education, including the calculation of criteria and indicators for assessing the educational services quality. 


\section{Results}

At the present stage, educational services are an integral part of the education system. The assessment of the quality of educational services is based on meeting the needs of students, creating conditions for learning, as well as focusing on personal development and effective competitiveness in the educational services market.

The formation of consumer expectations can be influenced by many factors: the student's own needs, life experience, the opinion of society, the status of the educational organization, current information about the labor market. Depending on the ratio of the assessment, the reasons for the gaps between the expectation and the perception of the quality of educational services highlighted: the assessment by the management of the educational organization of the consumer's expectations without research; untimely elimination of problems in the educational services.

The assessment of educational services quality in fact should proceed from the perception of its potential result, directly the student receives the educational service.

In practice, there is also a method for evaluating educational services based on the results of a preliminary survey of the consumers. This analysis will allow the educational organization to assess the entire process of providing a service from the initial stage - the conditions of obtaining, to the final result - the possibility of learning (BERZINA; ZICMANE; KUCKOVSKIS, 2017).

The information database for assessing the educational services quality can be the results of a survey separately for each consumer, the results of self-examination. Thus, evaluation of the quality of educational services carries out using methods (differential, complex or mixed) and consider the data obtained from the consumer survey.

In order to determine a quantitative assessment of educational services quality, it seems appropriate the main directions of educational activities (criteria). The particular indicators will characterize criteria. The authors proposed to use a complex method, which consists in the use of a consolidated quality indicator (composite coefficient), which interprets the quality level as a single factor.

Each of the coefficients characterize the criteria of educational services quality. It describes by several indicators with their weight (Table 1). The criteria for assessing the quality of educational services should be determined in accordance with the objectives of the educational organization functioning. The number of criteria should be sufficient to conduct an effective assessment. 
Table 1 - The criterion and the indicators of educational services quality

\begin{tabular}{|c|c|c|c|c|}
\hline № & Indicators & Calculation formula & Explanation of the formula & $\begin{array}{l}\text { Indicator } \\
\text { weight }\end{array}$ \\
\hline 1 & \multicolumn{4}{|c|}{ The criterion "Quality of HE educational programs" $\left(\mathrm{Cr}_{1}\right)$} \\
\hline 1.1 & $\begin{array}{l}\text { The share of educational } \\
\text { programs implemented under } \\
\text { double degree programs }\left(\mathrm{C}_{\text {d.d.p. }}\right)\end{array}$ & $C_{\text {d.d.p. }}=N_{\text {d.d.p. }} / \mathrm{N}_{\text {e.p. }}$ & $\begin{array}{l}\mathrm{N}_{\text {d.d.p. }}-\text { the number of } \\
\text { double degree programs; } \\
\mathrm{N}_{\text {e.p. }}-\text { the total number of } \\
\text { educational programs }\end{array}$ & $a_{1}$ \\
\hline 1.2 & $\begin{array}{l}\text { The share of network programs } \\
\text { implemented in cooperation with } \\
\text { leading Russian universities }\left(C_{n}\right)\end{array}$ & $C_{n}=N_{n} / N_{\text {e.p. }}$ & $\begin{array}{l}\mathrm{N}_{\mathrm{n}} \text { - the number of network } \\
\text { programs implemented in } \\
\text { cooperation with leading } \\
\text { Russian universities }\end{array}$ & $a_{2}$ \\
\hline 1.3 & $\begin{array}{l}\text { The share of educational } \\
\text { programs implemented in foreign } \\
\text { languages }\left(\mathrm{C}_{\mathrm{f} .1 .}\right)\end{array}$ & $C_{\text {f.l. }}=N_{\text {f.1. }} / N_{\text {e.p. }}$ & 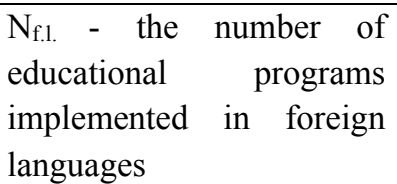 & $a_{3}$ \\
\hline 1.4 & $\begin{array}{l}\text { The share of students studying on } \\
\text { individual trajectories of } \\
\text { development }\left(\mathrm{C}_{\text {i.t.d. }}\right)\end{array}$ & $\mathrm{C}_{\text {i.t.t. }}=\mathrm{N}_{\mathrm{i} \text {..t.d. }} / \mathrm{N}_{\text {t.n.s. }}$ & $\begin{array}{l}\mathrm{N}_{\mathrm{i} \text {.t.d. }}-\text { the number of } \\
\text { students studying on } \\
\text { individual trajectories of } \\
\text { development; } \\
\mathrm{N}_{\text {t.n.s }} \text { - the total number of } \\
\text { students }\end{array}$ & $\mathrm{a}_{4}$ \\
\hline 1.5 & $\begin{array}{l}\text { The share of e-learning courses } \\
\text { hosted at the International and } \\
\text { Russian educational digital } \\
\text { platforms }\left(\mathrm{C}_{\text {e.c.d.p. }}\right)\end{array}$ & $C_{\text {e.c.d.p. }}=\mathrm{N}_{\text {e.c.d.p. }} / \mathrm{N}_{\text {e.c. }}$ & $\begin{array}{l}\mathrm{N}_{\text {e.c.d.p. }} \text { - the number of e- } \\
\text { learning courses hosted at } \\
\text { the International and } \\
\text { Russian educational digital } \\
\text { platforms; } \\
\mathrm{N}_{\text {e.c. }} \text { - the total number of e- } \\
\text { learning courses }\end{array}$ & $a_{5}$ \\
\hline 1.6 & $\begin{array}{l}\text { The share of graduates satisfied } \\
\text { with the quality of education } \\
\left(\mathrm{C}_{\text {g.q.e. }}\right)\end{array}$ & $C_{\text {g.q.e. }}=N_{\text {g.q.e. }} / \mathrm{N}_{\mathrm{g} .}$ & $\begin{array}{l}\mathrm{N}_{\text {g.q.e. }}-\text { the number of } \\
\text { graduates satisfied with the } \\
\text { quality of education; } \\
\mathrm{N}_{\text {g. }}-\text { the total number of } \\
\text { graduates }\end{array}$ & $\mathrm{a}_{6}$ \\
\hline 1.7 & $\begin{array}{l}\text { The share of students satisfied } \\
\text { with the quality of educational } \\
\text { programs }\left(\mathrm{C}_{\text {s.q.e. .p. }}\right)\end{array}$ & $C_{\text {s.q.e.p. }}=\mathrm{N}_{\text {s.q.e.p. }} / \mathrm{N}_{\text {t..n.s }}$ & $\begin{array}{l}\mathrm{N}_{\text {s.q.e.p. }}-\text { the number of } \\
\text { students satisfied with the } \\
\text { quality of educational } \\
\text { programs }\end{array}$ & $a_{7}$ \\
\hline 1.8 & $\begin{array}{l}\text { The share of SSE program's } \\
\text { graduates continued studies in HE } \\
\text { programs }\left(C_{\text {g. SSE HE }}\right)\end{array}$ & 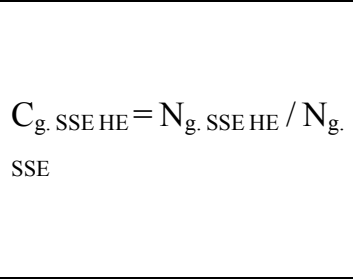 & $\begin{array}{l}\mathrm{N}_{\mathrm{g} . \text { SSE HE }} \text { - the number of } \\
\text { SSE program's graduates } \\
\text { continued studies in HE } \\
\text { programs; } \\
\mathrm{N}_{\text {g. SSE - the total number of }} \\
\text { SSE program's graduates }\end{array}$ & $a_{8}$ \\
\hline 1.9 & $\begin{array}{l}\text { The share of bachelor course } \\
\text { students continued studies in } \\
\text { master's degree program }\left(\mathrm{C}_{\text {s.b.m. }}\right)\end{array}$ & $\mathrm{C}_{\text {s.b. } \mathrm{m}}=\mathrm{N}_{\text {s.b.m. }} / \mathrm{N}_{\text {s.b. }}$ & $\begin{array}{l}\mathrm{N}_{\text {s.b.m }}-\text { the number of } \\
\text { bachelor course students } \\
\text { continued studies in } \\
\text { master's degree program; } \\
\mathrm{N}_{\text {s.b. }}-\text { the total number of } \\
\text { bachelor course students }\end{array}$ & $\mathrm{a}_{9}$ \\
\hline
\end{tabular}




\begin{tabular}{|c|c|c|c|c|}
\hline № & Indicators & Calculation formula & Explanation of the formula & $\begin{array}{l}\text { Indicator } \\
\text { weight }\end{array}$ \\
\hline 1.10 & $\begin{array}{l}\text { The share of HE program's } \\
\text { students studied under contracts } \\
\text { for targeted training }\left(\mathrm{C}_{\text {t.t. }}\right)\end{array}$ & $\mathrm{C}_{\text {t.t. }}=\mathrm{N}_{\text {t.t. }} / \mathrm{N}_{\text {t.n.s }}$ & $\begin{array}{l}\mathrm{N}_{\mathrm{t.t.}}-\text { the number of } \\
\text { students of HE programs } \\
\text { studied under contracts for } \\
\text { targeted training }\end{array}$ & $\mathrm{a}_{10}$ \\
\hline 2 & \multicolumn{4}{|c|}{ The criterion "Quality of the teaching staff" $\left(\mathrm{Cr}_{2}\right)$} \\
\hline 2.1 & $\begin{array}{l}\text { The share of teaching staff up to } \\
39 \text { years old }\left(\mathrm{C}_{\text {age }}\right)\end{array}$ & $\mathrm{C}_{\mathrm{age}}=\mathrm{N}_{\text {up to } 39} / \mathrm{N}_{\text {t.s. }}$ & $\begin{array}{l}\mathrm{N}_{\text {up to } 39} \text { - the number of } \\
\text { teaching staff up to } 39 \\
\text { years old; } \\
\mathrm{N}_{\text {t.s. }} \text { - total number of } \\
\text { teaching staff }\end{array}$ & $\mathrm{b}_{1}$ \\
\hline 2.2 & $\begin{array}{l}\text { The share of teaching staff with a } \\
\text { scientific degree }\left(\mathrm{C}_{\text {s.d. }}\right)\end{array}$ & $\mathrm{C}_{\text {s.d. }}=\mathrm{N}_{\text {s.d. }} / \mathrm{N}_{\mathrm{t.s}}$ & $\begin{array}{l}\mathrm{N}_{\text {s.d. }}-\text { the number of } \\
\text { teaching staff with a } \\
\text { scientific degree }\end{array}$ & $\mathrm{b}_{2}$ \\
\hline 2.3 & $\begin{array}{l}\text { The share of teaching staff with a } \\
\text { PhD degree }\left(\mathrm{C}_{\mathrm{PhD}}\right)\end{array}$ & $\mathrm{C}_{\mathrm{PhD}}=\mathrm{N}_{\mathrm{PhD}} / \mathrm{N}_{\mathrm{t} . \mathrm{s} .}$ & $\begin{array}{l}\mathrm{N}_{\mathrm{PhD}} \text { - the number of } \\
\text { teaching staff with a } \mathrm{PhD} \\
\text { degree }\end{array}$ & $\mathrm{b}_{3}$ \\
\hline 2.4 & $\begin{array}{l}\text { The share of teaching staff who } \\
\text { speak a foreign language }\left(\mathrm{C}_{\mathrm{f} . \mathrm{l} .}\right)\end{array}$ & $\mathrm{C}_{\mathrm{f} .1 .}=\mathrm{N}_{\mathrm{f} . \mathrm{l} .} / \mathrm{N}_{\mathrm{t} . \mathrm{s}}$ & $\begin{array}{l}\mathrm{N}_{\text {f.l. }}-\text { the number of } \\
\text { teaching staff who speak a } \\
\text { foreign language }\end{array}$ & $\mathrm{b}_{4}$ \\
\hline 2.5 & $\begin{array}{l}\text { The share of teaching staff who } \\
\text { have completed internships with } \\
\text { leading employers and abroad, per } \\
\text { year }\left(C_{\text {in. }}\right)\end{array}$ & $\mathrm{C}_{\text {in. }}=\mathrm{N}_{\text {in. }} / \mathrm{N}_{\mathrm{t.s} .}$ & $\begin{array}{l}\mathrm{N}_{\text {in. }}-\text { the number of } \\
\text { teaching staff who have } \\
\text { completed internships with } \\
\text { leading employers and } \\
\text { abroad }\end{array}$ & $b_{5}$ \\
\hline 2.6 & $\begin{array}{l}\text { The share of students satisfied } \\
\text { with the quality of the of lessons } \\
\left(\mathrm{C}_{\mathrm{q} .1 .}\right)\end{array}$ & $\mathrm{C}_{\mathrm{q} . \mathrm{l} .}=\mathrm{N}_{\mathrm{q} . \mathrm{l} .} / \mathrm{N}_{\mathrm{t} . \mathrm{n} . \mathrm{s}}$ & $\begin{array}{l}\mathrm{N}_{\mathrm{q} . \mathrm{l}}-\text { the number of } \\
\text { students who are satisfied } \\
\text { with the quality of lessons }\end{array}$ & $\mathrm{b}_{6}$ \\
\hline 3 & \multicolumn{4}{|c|}{ The criterion "Quality of educational technologies" $\left(\mathrm{Cr}_{3}\right)$} \\
\hline 3.1 & $\begin{array}{l}\text { The share of teaching staff using } \\
\text { interactive methods (training, } \\
\text { coaching, gaming practices and so } \\
\text { on.) }\left(C_{\text {i.m. }}\right)\end{array}$ & $C_{\text {i.m. }}=N_{i . m .} / N_{t . s .}$ & $\begin{array}{l}\mathrm{N}_{\mathrm{i} . \mathrm{m} .} \text { - the number of } \\
\text { teaching staff using } \\
\text { interactive methods }\end{array}$ & $\mathrm{c}_{1}$ \\
\hline 3.2 & $\begin{array}{l}\text { The share of teaching staff using } \\
\text { modern electronic educational } \\
\text { resources, including their own } \\
\text { developments (e-learning courses, } \\
\text { Coursera, video lectures, content } \\
\text { courses })\left(\mathrm{C}_{\text {e.e.r. }}\right)\end{array}$ & $C_{\text {e.e.r. }}=N_{\text {e.e.r. }} / \mathrm{N}_{\text {t.s. }}$ & $\begin{array}{l}\mathrm{N}_{\text {e.e.r. }} \text { - the number of } \\
\text { teaching staff using } \\
\text { modern } \\
\text { educational electronic } \\
\text { including their own } \\
\text { developments }\end{array}$ & $\mathrm{c}_{2}$ \\
\hline 3.3 & $\begin{array}{l}\text { The share of teaching staff using a } \\
\text { training project-based approach } \\
\left(\mathrm{C}_{\mathrm{pr}}\right)\end{array}$ & $\mathrm{C}_{\mathrm{pr}}=\mathrm{N}_{\mathrm{pr}} / \mathrm{N}_{\mathrm{t} . \mathrm{s}}$ & $\begin{array}{l}N_{\text {pr }} \text { - the number of } \\
\text { teaching } \text { staff using a } \\
\text { training } \\
\text { approach }\end{array}$ & $c_{3}$ \\
\hline 3.4 & $\begin{array}{l}\text { The share of educational } \\
\text { programs developed using } \\
\text { inclusive technologies and } \\
\text { methods }\left(\mathrm{C}_{\mathrm{inc}}\right)\end{array}$ & $\mathrm{C}_{\text {inc }}=\mathrm{N}_{\text {inc }} / \mathrm{N}_{\text {e.p. }}$ & $\begin{array}{l}\mathrm{N}_{\text {inc }}-\text { the number of } \\
\text { educational programs } \\
\text { developed using inclusive } \\
\text { technologies and methods }\end{array}$ & $\mathrm{c}_{4}$ \\
\hline 3.5 & $\begin{array}{l}\text { The share of teaching staff who } \\
\text { have learned the methods of } \\
\text { inclusive education }\left(\mathrm{C}_{\text {inc. ed. }}\right)\end{array}$ & $\mathrm{C}_{\text {inc. ed. }}=\mathrm{N}_{\text {inc. ed. }} / \mathrm{N}_{\text {t.s. }}$ & $\begin{array}{l}\mathrm{N}_{\text {inc. ed. }} \text { - the number of } \\
\text { teaching staff who have } \\
\text { learned the methods of } \\
\text { inclusive education }\end{array}$ & $\mathrm{c}_{5}$ \\
\hline
\end{tabular}




\begin{tabular}{|c|c|c|c|c|}
\hline № & Indicators & Calculation formula & Explanation of the formula & $\begin{array}{l}\text { Indicator } \\
\text { weight }\end{array}$ \\
\hline 3.6 & $\begin{array}{l}\text { The share of teaching staff } \\
\text { received communication and } \\
\text { media skills }\left(\mathrm{C}_{\text {c.m.s. }}\right)\end{array}$ & $\mathrm{C}_{\mathrm{c} . \mathrm{m} . \mathrm{s} .}=\mathrm{N}_{\mathrm{k} . \mathrm{m} . \mathrm{s}} / \mathrm{N}_{\mathrm{t} . \mathrm{s} .}$ & $\begin{array}{l}\mathrm{N}_{\text {c.m.s. }}-\text { the number of } \\
\text { teaching staff received } \\
\text { communication and media } \\
\text { skills }\end{array}$ & $\mathrm{c}_{6}$ \\
\hline 4 & \multicolumn{4}{|c|}{ The criterion "Quality of material and technical support of the educational process" $\left(\mathrm{Cr}_{4}\right)$} \\
\hline 4.1 & $\begin{array}{l}\text { The level of student's satisfaction } \\
\text { with digital services }\left(\mathrm{C}_{\text {s.d.s. }}\right)\end{array}$ & $\mathrm{C}_{\text {s.d.s. }}=\mathrm{N}_{\text {s.d.s. }} / \mathrm{N}_{\text {t.n.s }}$ & $\begin{array}{l}\mathrm{N}_{\text {s.d.s. }} \text { the number of } \\
\text { students satisfied with } \\
\text { digital services }\end{array}$ & $\mathrm{d}_{1}$ \\
\hline 4.2 & $\begin{array}{l}\text { The level of teaching staff } \\
\text { satisfaction with digital services } \\
\left(\mathrm{C}_{\text {t.s.d.s. }}\right)\end{array}$ & $\mathrm{C}_{\text {t.s.d.s. }}=\mathrm{N}_{\text {t.s.d.s. }} / \mathrm{N}_{\text {t.s. }}$ & $\begin{array}{l}\mathrm{N}_{\text {t.s.d.s. }}-\text { number of teaching } \\
\text { staff satisfied with digital } \\
\text { services }\end{array}$ & $d_{2}$ \\
\hline 4.3 & $\begin{array}{l}\text { The level of provision of } \\
\text { educational and scientific } \\
\text { processes with modern equipment } \\
\left(\mathrm{C}_{\text {m.eq. }}\right)\end{array}$ & $\mathrm{C}_{\mathrm{m} . \text { eq. }}=\mathrm{N}_{\mathrm{m} . \mathrm{eq} .} / \mathrm{N}_{\mathrm{eq}}$ & $\begin{array}{l}\mathrm{N}_{\text {m.eq. }}-\text { the amount of } \\
\text { modern equipment; } \\
\mathrm{N}_{\text {eq. }}-\text { the number of } \\
\text { installed equipment }\end{array}$ & $d_{3}$ \\
\hline 4.4 & $\begin{array}{l}\text { The level of teaching staff } \\
\text { satisfaction with the quality of the } \\
\text { educational and scientific } \\
\text { infrastructure }\left(\mathrm{C}_{\text {t..s.e.s.i. }}\right)\end{array}$ & $\mathrm{C}_{\mathrm{t} . \text {.s.e.s.i. }}=\mathrm{N}_{\mathrm{t} \text { t.s.e.s.i. }} / \mathrm{N}_{\mathrm{t} \text { t.s. }}$ & $\begin{array}{l}\mathrm{N}_{\text {t.se.s.i }} \text { - the number of } \\
\text { teaching staff satisfied with } \\
\text { the quality of the } \\
\text { educational and scientific } \\
\text { infrastructure }\end{array}$ & $\mathrm{d}_{4}$ \\
\hline 4.5 & $\begin{array}{l}\text { The level of student's satisfaction } \\
\text { with the quality of educational } \\
\text { and scientific infrastructure } \\
\left(\mathrm{C}_{\text {s.e.s.s. }}\right)\end{array}$ & $\mathrm{C}_{\text {s.e.s.i. }}=\mathrm{N}_{\text {s.e.s.i. }} / \mathrm{N}_{\mathrm{t} \text {.n.s }}$ & $\begin{array}{l}\mathrm{N}_{\text {s.e.s.i. }} \text { the number of } \\
\text { students satisfied with the } \\
\text { quality of the educational } \\
\text { and scientific infrastructure }\end{array}$ & $\mathrm{d}_{5}$ \\
\hline 5 & \multicolumn{4}{|c|}{ The criterion "Quality of educational processes management" $\left(\mathrm{Cr}_{5}\right)$} \\
\hline 5.1 & $\begin{array}{l}\text { The level of student's satisfaction } \\
\text { with the work of Centralized } \\
\text { Dean's office }\left(\mathrm{C}_{\text {s.C.D.o. }}\right)\end{array}$ & $C_{\text {s.C.D.o. }}=\mathrm{N}_{\text {s.C.D.o }} / \mathrm{N}_{\text {t.n.s }}$ & $\begin{array}{l}\mathrm{N}_{\text {s.C.D.o. }}-\text { the number of } \\
\text { students satisfied with the } \\
\text { work of the Centralized } \\
\text { Dean's Office }\end{array}$ & $\mathrm{e}_{1}$ \\
\hline 5.2 & $\begin{array}{l}\text { The level of teaching staff } \\
\text { satisfaction with the work of } \\
\text { Centralized Dean's office } \\
\text { (Ct.s.C.D.o. })\end{array}$ & $\mathrm{C}_{\text {t.s.C.D.o. }}=\mathrm{N}_{\text {t.s.C.D. }}$.o. $/ \mathrm{N}_{\mathrm{t} \text { t.s. }}$ & $\begin{array}{l}\mathrm{N}_{\text {t.s.C.D.o. }}-\text { the number of } \\
\text { teaching staff satisfied with } \\
\text { the work of the Centralized } \\
\text { Dean's Office }\end{array}$ & $\mathrm{e}_{2}$ \\
\hline 5.3 & $\begin{array}{l}\text { The level of student's satisfaction } \\
\text { with the Technical Support } \\
\text { Service }\left(C_{\text {s.t.s.s. }}\right)\end{array}$ & $\mathrm{C}_{\text {s.T.S.S. }}=\mathrm{N}_{\text {s.T.S.S }} / \mathrm{N}_{\text {t.n.s }}$ & $\begin{array}{l}\mathrm{N}_{\text {s.T.S.S }}-\text { the number of } \\
\text { students satisfied with the } \\
\text { Technical Support Service }\end{array}$ & $\mathrm{e}_{3}$ \\
\hline 5.4 & $\begin{array}{l}\text { The level of teaching staff } \\
\text { satisfaction with the Technical } \\
\text { Support Service }\left(\mathrm{C}_{\text {t.s. }} \text {. S.S. }\right)\end{array}$ & $\mathrm{C}_{\text {t.s.T.S.S. }}=\mathrm{N}_{\text {t.s.T.S.S. }} / \mathrm{N}_{\mathrm{t} \text {.s }}$ & $\begin{array}{l}\mathrm{N}_{\text {t.s.T.S.S. }} \text { the number of } \\
\text { teaching staff satisfied with } \\
\text { the Technical Support } \\
\text { Service }\end{array}$ & $\mathrm{e}_{4}$ \\
\hline 5.5 & $\begin{array}{l}\text { The level of student's satisfaction } \\
\text { with the current regulations and } \\
\text { local regulations }\left(\mathrm{C}_{\text {s.c.l.r. }}\right)\end{array}$ & $\mathrm{C}_{\text {s.c.l.r. }}=\mathrm{N}_{\text {s.c.l.r. }} / \mathrm{N}_{\mathrm{t} \text { t. } . \mathrm{s}}$ & $\begin{array}{l}\mathrm{N}_{\text {s.c.l.r. }}-\text { the number of } \\
\text { students satisfied with the } \\
\text { current regulations and } \\
\text { local regulations }\end{array}$ & $\mathrm{e}_{5}$ \\
\hline 5.6 & $\begin{array}{l}\text { The level of teaching staff } \\
\text { satisfaction the with the current } \\
\text { regulations and local regulations } \\
\left.\text { ( } \mathrm{C}_{\text {t.s.c.l.r. }}\right)\end{array}$ & $\mathrm{C}_{\text {t.s.c.l.1.r. }}=\mathrm{N}_{\mathrm{t} \text { t.s. l...r. }} / \mathrm{N}_{\mathrm{t} . \mathrm{s}}$ & $\begin{array}{l}\mathrm{N}_{\text {t.s.c.l.r. }}-\text { number of teaching } \\
\text { staff satisfied the with the } \\
\text { current regulations and } \\
\text { local regulations }\end{array}$ & $\mathrm{e}_{6}$ \\
\hline
\end{tabular}

Source: Devised by the authors 
Further, an expert assign a weight to each criterion. This weight considers in calculating the composite coefficient of educational services quality (Table 2).

Table 2 - The criteria of educational services quality

\begin{tabular}{|c|c|c|c|}
\hline № & Criteria & Calculation formula & $\begin{array}{l}\text { Criterion } \\
\text { weight }\end{array}$ \\
\hline 1 & $\begin{array}{l}\text { The criterion "Quality of } \mathrm{HE} \\
\text { educational programs" }\left(\mathrm{Cr}_{1}\right)\end{array}$ & $\begin{array}{l}\mathrm{Cr}_{1}=\mathrm{a}_{1} \mathrm{C}_{\text {d.d.p. }}+\mathrm{a}_{2} \mathrm{C}_{\mathrm{n}}+\mathrm{a}_{3} \mathrm{C}_{\text {f.l. }}+\mathrm{a}_{4} \mathrm{C}_{\text {i.t.d. }+}+\mathrm{a}_{5} \mathrm{C}_{\text {e.c.d.p. }}+\mathrm{a}_{6} \\
\mathrm{C}_{\text {g.q.e. }}+\mathrm{a}_{7} \mathrm{C}_{\text {s.q.e.p. }}+\mathrm{a}_{8} \mathrm{C}_{\mathrm{g} . \mathrm{SSE}} \mathrm{HE}+\mathrm{a}_{9} \mathrm{C}_{\text {s.b.m }}+\mathrm{a}_{10} \mathrm{C}_{\text {t.t. }}\end{array}$ & $\mathrm{n}_{1}$ \\
\hline 2 & $\begin{array}{l}\text { The criterion "Quality of the } \\
\text { teaching staff" }\left(\mathrm{Cr}_{2}\right)\end{array}$ & $\begin{array}{l}\mathrm{Cr}_{2}=\mathrm{b}_{1} \mathrm{C}_{\mathrm{age}}+\mathrm{b}_{2} \mathrm{C}_{\text {s.d. }}+\mathrm{b}_{3} \mathrm{C}_{\mathrm{PhD}}+\mathrm{b}_{4} \mathrm{C}_{\mathrm{f} . \mathrm{l} .}+\mathrm{b}_{5} \mathrm{C}_{\mathrm{in.} .}+ \\
\mathrm{b}_{6} \mathrm{C}_{\mathrm{q} . \mathrm{l} .}\end{array}$ & $\mathrm{n}_{2}$ \\
\hline 3 & $\begin{array}{l}\text { The criterion "Quality of } \\
\text { educational technologies" }\left(\mathrm{Cr}_{3}\right)\end{array}$ & $\begin{array}{l}\mathrm{Cr}_{3}=\mathrm{c}_{1} \mathrm{C}_{\mathrm{i} . \mathrm{m} .}+\mathrm{c}_{2} \mathrm{C}_{\text {e.e.r. }}+\mathrm{c}_{3} \mathrm{C}_{\mathrm{pr}}+\mathrm{c}_{4} \mathrm{C}_{\mathrm{inc}}+\mathrm{c}_{5} \mathrm{C}_{\text {inc. ed. }} \\
+\mathrm{c}_{6} \mathrm{C}_{\text {c.m.s. }}\end{array}$ & $\mathrm{n}_{3}$ \\
\hline 4 & $\begin{array}{l}\text { The criterion "Quality of material } \\
\text { and technical support of the } \\
\text { educational process" }\left(\mathrm{Cr}_{4}\right)\end{array}$ & $\begin{array}{l}\mathrm{Cr}_{4}=\mathrm{d}_{1} \mathrm{C}_{\text {s.d.s. }} \mathrm{d}_{2} \mathrm{KC}_{\text {t.s.d.s. }}+\mathrm{d}_{3} \mathrm{C}_{\text {m.eq. }}+\mathrm{d}_{4} \mathrm{C}_{\text {t.s.e.s.i. }}+\mathrm{d}_{5} \\
\mathrm{C}_{\text {s.e.s.i. }}\end{array}$ & $\mathrm{n}_{4}$ \\
\hline 5 & $\begin{array}{l}\text { The criterion "Quality of } \\
\text { educational processes } \\
\text { management" }\left(\mathrm{Cr}_{5}\right)\end{array}$ & $\begin{array}{l}\mathrm{Cr}_{5}=\mathrm{e}_{1} \mathrm{C}_{\text {s.C.D.o. }}+\mathrm{e}_{2} \mathrm{C}_{\text {t.s.C.D.o. }}+\mathrm{e}_{3} \mathrm{C}_{\text {s.T.S.S. }}+\mathrm{e}_{4} \\
\mathrm{C}_{\text {t.s.T.S.S. }}+\mathrm{e}_{5} \mathrm{C}_{\text {s.c.l.r. }}+\mathrm{e}_{6} \mathrm{C}_{\text {t.s.c.l.r. }}\end{array}$ & $\mathrm{n}_{5}$ \\
\hline
\end{tabular}

Source: Devised by the authors

The composite coefficient of educational services quality $\left(\mathrm{C}_{\text {e.s.q. }}\right)$ is determined as the sum of generalizing indicators for each criterion, considering the weight. It determines by the formula:

$$
\text { Ce.s.q. }=\mathrm{n}_{1} \mathrm{Cr}_{1}+\mathrm{n}_{2} \mathrm{Cr}_{2}+\mathrm{n}_{3} \mathrm{Cr}_{3}+\mathrm{n}_{4} \mathrm{Cr}_{4}+\mathrm{n}_{5} \mathrm{Cr}_{6} \text {, }
$$

Thus, the composite coefficient makes it possible to assess the quality of educational services in quantitative terms, the maximum value of which will be one. In the future, it will be possible to compare the composite coefficient and particular indicators, considering their weight, with the previous year's coefficients.

It is effectively to use a mixed method for assessing the quality of educational services. The indicators, criteria and a composite indicator (integrated method) will first be determined. Then a differential method based on a comparison of quality indicators of the base and current periods will be applied.

The criterion and indicators will have its own characteristics to each educational institution, so the internal audit has individual character. 


\section{Discussion}

The study of the assessment of educational services quality emphasized the need for an effective assessment through the implementation of an internal audit. The internal audit should be organized on a regular basis in order to trace the dynamics of changes in indicators and obtain reliable results. It will allow us to take timely measures to improve the quality of educational services. Based on the results of the internal audit, university can plan and carry out measures for effective management of the educational process. It will improve the quality of educational services, meet the needs of consumers and the requirements of Federal state Educational Standards (RUSSIA, [s.d.]).

The methods for assessing the quality of educational services studied in the work made it possible to distinguish two main stages:

1) The analysis of reports of the educational organization activities;

2) The analysis of sociological surveys.

Meanwhile, it was determined that in order to assess the quality of educational services effectively, it is necessary to analyze the data throughout the entire period of providing educational services. Moreover, in order to increase competitiveness and achieve leading positions as at the educational services market and the labor market, education and professional training institutions is advisable not only to maintain a certain level of quality of educational services, but also to ensure its increase.

The number of researchers emphasized the need to improve the procedure for assessing the quality of educational services. They identified the questionnaire with open and closed questions as one of the effective methods of assessing, involving the use of scoring parameters and the method of weighted estimates (GOLUBEVA; MEREUTS; TKHAZAPLIZHEVA, 2017). The objectivity of the survey results depends on the number of questions. That's why it is important to study in detail the questionnaires for each consumer on a specific educational process (BAYDAKOVA; KOMIN; ALMAMATOV, 2015).

The results of the analysis of the educational services quality assessment emphasize the need to improve efficiency through the determination of the management system, including all management levels of the educational organization (BASYUK; ANTIPENKO, 2019). 


\section{Conclusion}

Thus, in order to establish and develop an effective system for assessing the educational services quality, educational organizations should apply methods of comprehensive assessment, which depends on the internal organization of educational activities. Therefore, if educational activity is a service, the assessment parameters defined by internal standards may apply to it. The educational services should have the features that characterize their quality and satisfy the interests of consumers. However, it is important to emphasize that the choice of methods for assessing the educational services quality should consider the requirements determined by the objectives of the study, as well as adapt to specific levels of education and categories of consumers. The developed methodology is complex. It allows the educational organizations to consider both the data of monitoring the educational services quality and the data of sociological surveys of students of various courses and areas of training and the teaching staff of the university.

\section{REFERENCES}

ASANOVA, I. M.; SYRTSEV, A. N. Internal Audit Methodology. 2019. Available: https://akvobr.ru/metodika_vnutrennego_audita.html. Access: 15 Oct. 2020.

BASYUK, A. S.; ANTIPENKO, R. V. Assessment of the quality of educational services of the university. Scientific Bulletin of the Southern Institute of Management, v. 4, p. 123$117,2019$.

BAYDAKOVA, A.; KOMIN, M.; ALMAMATOV, A. Factors of unreliability of the results of sociological surveys. 2015. Available: http://www.cogita.ru/a.n.-alekseev/andreialekseev-1/faktory-nedostovernosti-rezultatov-sociologicheskih-oprosov. Access: 12 Oct. 2020 .

BERZINA, K.; ZICMANE, I.; KUCKOVSKIS, J. Self-assessment as a key criterion for increase of quality of higher education in modern conditions. In: INTERNATIONAL CONFERENCE ON ELECTROMECHANICAL AND POWER SYSTEMS, 11., 2017. Proceedings [...]. 2017.

BOLOTOV, V. A. The past, present and possible future of the Russian system for assessing the quality of education. Education Issues, v. 3, p. 287-297, 2018.

CARCAMO, J. L. Factors associated with the teacher's practice that affect the dropout of students in the e-learning modality, a case study in the context of Chilean higher education. Ciencia e ingenieria, v. 42, n. 1, p. 101-112, 2021. 
ESCOBAR-JIMENEZ, C.; DELGADO, A. Quality and Quality in Higher Education: A Theoretical Discussion in Ecuadorian Higher Education System. Redu-Revista de Docencia Universitaria, v. 17, n. 2, p. 159-175, 2019.

GERRITSEN-VAN LEEUWENKAMP, K. J.; JOOSTEN-TEN BRINKE, D.; KESTER, L. Assessment quality in tertiary education: An integrative literature review. Studies in Educational Evaluation, v. 55, p. 94-11, 2017.

GOLUBEVA, O. A.; MEREUTS, K. I.; TKHAZAPLIZHEVA, A. N. Assessment of the quality of educational services by assessing consumer satisfaction. Science today: problems and development prospects, p. 31-33, 2017.

GONZALEZ-GERALDO, J. L.; MONROY, F.; DEL RINCON IGEA, B. Impact of a Spanish higher education teacher development programme on approaches to teaching. Psychometric properties of the s-ati-20 scale. Educacion XXI, v. 24, n. 1, p. 213-232, 2021.

ILICHENKO, I. A. The quality of educational services: factors, problems, prospects. In: Problems of the quality of education. Psychological and pedagogical aspects of the humanitarian culture of society. Management in regional socio-economic systems. Taganrog: Publishing CHOU VO TIUiE, 2017. p. 114-148.

PANASYUK, V. P. Management of education and educational systems: state, trends, problems and prospects. Education and Science, v. 2, p. 72-88, 2017.

RUSSIA. Federal Law, No. 273-FZ. On Education in the Russian Federation. 2012. Available: http://www.consultant.ru/document/cons_doc_LAW_140174/. Access: 08 Oct. 2020 .

RUSSIA. GOST R 50691 - National standard of the Russian Federation. Services to the population. Service quality assurance system model. 2013. Available:

http://www.consultant.ru/document/cons_doc_LAW_267904/.Access: 08 Oct. 2020.

RUSSIA. Statistical reporting in the form "Form No. 1-Monitoring". Monitoring of the main activities of the educational organization of higher education. 2019. Available: http://www.consultant.ru/document/cons_doc_LAW_359722/. Access: 08 Oct. 2020.

RUSSIA. Federal state educational standards. Reference information. [s.d.]. Available: http://www.consultant.ru/document/cons_doc_LAW_142304/\#dst0. Access: 08 Oct. 2020.

SERGEEVA, S. Y. Modern approaches and methods for assessing the quality of education. Young scientist, v. 37, n. 275, p. 162-165, 2019. 
VELICHKO, N. Y. et al. Satisfaction of consumers of educational services as a factor contributing to improving the quality of services. 2020. Available:

hhttp://www.tsutmb.ru/nayk/nauchnyie_meropriyatiya/int_konf/vseross/professionalno_lichn ostnoe_razvitie_prepodavatelya_i_studenta_tradiczii,_problemyi,_perspektivyi2/sekcziya_1/u dovletvorennost_potrebitelej_obrazovatelnyix_uslug. Access: 08 Oct. 2020.

VERETEKHINA, S. V.; NOVIKOVA, V. A. Transformation of education in the digital economy. Contemporary Problems of Social Work, v. 5, n. 2(18), p. 30-37, 2019.

ZHANG, A.; LI, G.; LI, Z. Research on High Quality Development of Higher Education. In: INTERNATIONAL CONFERENCE ON HUMANITIES AND SOCIAL SCIENCE RESEARCH (ICHSSR) GUILIN, PEOPLES R CHINA, 5., 2019. Proceedings [...]. 2019. p. $472-475$.

\section{How to reference this article}

VINOGRADOVA, M.; KULYAMINA, O.; VASILEVA. L.; BRONNIKOVA, E.; VISHNYAKOVA, V. Methodology for assessing the quality of educational services in higher education. Revista on line de Política e Gestão Educacional, Araraquara, v. 25, n. esp. 6, p. 3538-3549, $\quad$ Dec. 2021. e-ISSN:1519-9029. https://doi.org/10.22633/rpge.v25iesp.6.16115

Submitted: 07/04/2021

Required revisions: 19/08/2021

Approved: 25/11/2021

Published: 30/12/2021

Processing and publication by the Editora Ibero-Americana de Educação. Correction, formatting, standardization and translation.

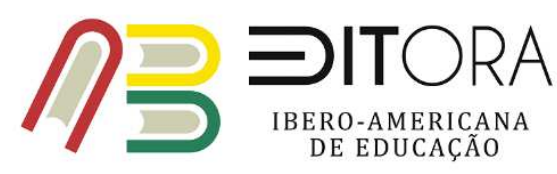

